\title{
POLYMERASE CHAIN REACTION FOR THE LABORATORY DIAGNOSIS OF ASEPTIC MENINGITIS AND ENCEPHALITIS
}

\author{
MARISA CHESKY*, ROSANA SCALCO*, LUCIANE FAILACE**, \\ STEVEN READ ${ }^{* * *}$, LUIZ FERNANDO JOBIM****
}

\begin{abstract}
A protocol for testing cerebrospinal fluid specimens using a range of PCR assays for the diagnosis of central nervous system infection was developed and used to test prospectively 383 specimens. PCR assays were used for the detection of adenovirus, Borrelia burgdorferi, enteroviruses, Epstein Barr virus, cytomegalovirus, herpes simplex virus, human herpes virus type 6, JC virus, Leptospira interrogans, Listeria monocytogenes, lymphocytic choriomeningitis virus, measles virus, mumps virus, Mycobacterium sp., Mycoplasma pneumoniae, Toxoplasma gondii and varicella zoster virus. Of the 383 specimens tested in this study, 46 (12.0\%) were found to be positive. The microorganisms detected were CMV, enterovirus, Epstein Barr virus, herpes simplex virus, human herpes virus type 6, JC virus, L. monocytogenes, Mycobacterium genus, Toxoplasma gondii and varicella zoster virus. The introduction of the PCR protocol described has improved the diagnosis of a range of central nervous system infections in our laboratory. We believe however that further evaluation of these assays in immunocompromised patients is necessary to better determine the predictive value of positive PCR results in these patient groups.
\end{abstract}

KEY WORDS: polymerase chain reaction (PCR), cerebrospinal fluid (CSF), central nervous system (CNS), lymphocytic meningitis, encephalitis.

\section{Reação em cadeia da polimerase no diagnóstico laboratorial das meningites e encefalites assépticas}

RESUMO - Foi desenvolvido um protocolo de PCR para analisar os principais patógenos que infectam o sistema nervoso central (SNC). Foram testadas 383 amostras de líquido-cefalorraquidiano (LCR), para detecção de: adenovirus, Borrelia burgdorferi, enterovirus, vírus Epstein Barr , citomegalovírus, vírus herpes simplex, herpes humano tipo 6, vírus JC, Leptospira interrogans, Listeria monocytogenes, vírus da coriomeningite linfocitária, vírus do sarampo, vírus da caxumba, Mycobacterium sp, Mycoplasma pneumoniae, Toxoplasma gondii e vírus da varicela zoster. Das 383 amostras de LCR testadas a PCR foi positiva em 46 (12,0\%). Os microrganismos detectados foram: citomegalovírus, enterovirus, vírus Epstein Barr , herpes simplex, herpes humanao tipo 6, vírus JC, Listeria monocytogenes, Mycobacterium sp, Toxoplasma gondii e varicela zoster. A introdução da técnica de PCR através de um protocolo para análise do LCR otimizou o diagnóstico etiológico das infecções do SNC e tem se revelado um instrumento de grande potencial diagnóstico. Estudos futuros necessitam ser realizados para melhor avaliar os resultados da PCR em pacientes imunocomprometidos e assim determinar o valor preditivo positivo deste ensaio neste grupo de pacientes.

PALAVRAS-CHAVE: reação em cadeia da polimerase (PCR), líquido cefalorraquidiano (LCR), sistema nervoso central (SNC), meningite asséptica, encefalite.

Hospital de Clínicas de Porto Alegre, Universidade Federal do Rio Grande do Sul: *Biochemist, Immunology Unit, **Pediatric Immunologist (resident);***Clinical Virologist, Public Health Laboratory, Oxford, and Micropathology Ltd, University of Warwick Science Park, United Kingdom;****Associate Professor, Internal Medicine Department, Universidade Federal do Rio Grande do Sul; Chief, Immunology Unit, Hospital de Clínicas de Porto Alegre; Scientific Director, Laboratório DNA Reference, Brazil. Aceite: 3-julho-2000. 
The inflammatory processes which most commonly affect the central nervous system (CNS) are aseptic meningitis and encephalitis. Generally these diseases are caused by viruses, however, Toxoplasma gondii and Mycobacteria have been identified as causes of lymphocytic meningitis and encephalitis in immunocompromised patients. Conventional laboratory diagnostic methods, such as growth of a microorganism in culture and detection of specific antibody, are generally poor in the diagnosis of CNS infection. They are generally too slow, have low sensitivity and consequently they are of little use in diagnosing and treating the patient during the acute phase of the disease $\mathrm{e}^{1,2}$. In cases of aseptic meningitis and encephalitis, the rapid identification of the etiologic agent not only serves to elicit important epidemiological information, but, with the availability of antiviral drugs, helps to direct clinical procedures. More sensitive diagnostic assays may also improve our understanding of the etiology of CNS infections.

In the 1980's, the development of the polymerase chain reaction (PCR) technique revolutionized the analysis of nucleic acids, allowing the detection of DNA and RNA sequences in different types of clinical material ${ }^{3}$. PCR has widely used in infectious disease diagnosis, having a major impact in those areas that have been diagnostic difficulties, either because organisms cannot be cultivated, grow only slowly, or require a highly specific culture medium, such as viruses, certain bacteria, fungi, and protozoans $\mathrm{s}^{4-6}$.

Several studies have employed PCR for diagnosing CNS infections, especially for herpes simplex virus (HSV) encephalitis and for enterovirus meningitis: in patients with herpes encephalitis, studies comparing PCR of CSF with a 'gold standard' test (viral culture or viral antigen detection in brain biopsy) have demonstrated that PCR is highly sensitive and specific, in addition to being fast and less invasive ${ }^{7,8}$. In cases of enterovirus meningitis, the use of PCR has allowed rapid laboratory diagnosis, thus reducing the duration of hospital stay and avoiding the need for aggressive therapeutic measures ${ }^{9}$.

A report published in 1997 described the use of PCR assays arranged in an algorithm for the laboratory diagnosis of aseptic meningitis and encephalitis in the $\mathrm{UK}^{10,11}$. A similar PCR protocol was developed at Hospital de Clínicas de Porto Alegre, Brazil, with the aim of establishing a routine molecular diagnostic service for CNS infection and determining which are the most common CNS pathogens in the Porto Alegre area.

\section{METHOD}

PCR assays were used to prospectively test CSF specimens from 383 patients with presumed aseptic meningitis and encephalitis for the presence of 17 infectious agents. The following protocol was used: stage 1 comprised of assays for HSV, varicella zoster virus (VZV), and enteroviruses; stage 2 had assays for adenovirus, cytomegalovirus (CMV), Epstein Barr virus (EBV), human herpes virus 6 (HHV6), lymphocytic choriomeningitis virus (LCMV), measles virus, and mumps virus (patients with a known immunodeficiency were also tested for JC virus, Mycobacterium genus and T. gondii); stage 3 tested for Borrelia burgdorferi, Leptospira interrogans, Listeria monocytogenes, and Mycoplasma pneumoniae.

Microorganisms with a DNA genome were initially amplified without DNA extraction and purification: $10 \mu \mathrm{l}$ of CSF was added directly to PCRs with release of DNA achieved by heat denaturation of organisms during PCR incubations. However, after PCR amplification inhibition by components of some CSF specimens was detected, DNA extraction using the QIAamp viral RNA kit (QIAGEN Ltd, Crawley, UK) was added to the protocol. For viruses with an RNA genome, nucleic acid was initially extracted and purified from CSF using an in-house method in which virus particles were lysed with guanidine isothiocyanate and nucleic acid was bound to a suspension of silica particles ${ }^{12}$. This method was replaced by the QIAamp procedure so that DNA and RNA targets could be processed with a common protocol. The QIAamp procedure was performed according to the manufacturers instructions. All CSF specimens were submitted to routine biochemical, differential cytological and bacterioscopical examination.

PCR using nested primers was used for each of the targets. For some reactions, multiplex PCR using a combination of primers was used. The combined primers had similar annealing temperatures, and it was possible to distinctly identify each PCR product according to its electrophoretic mobility. Primers for the following micro- 


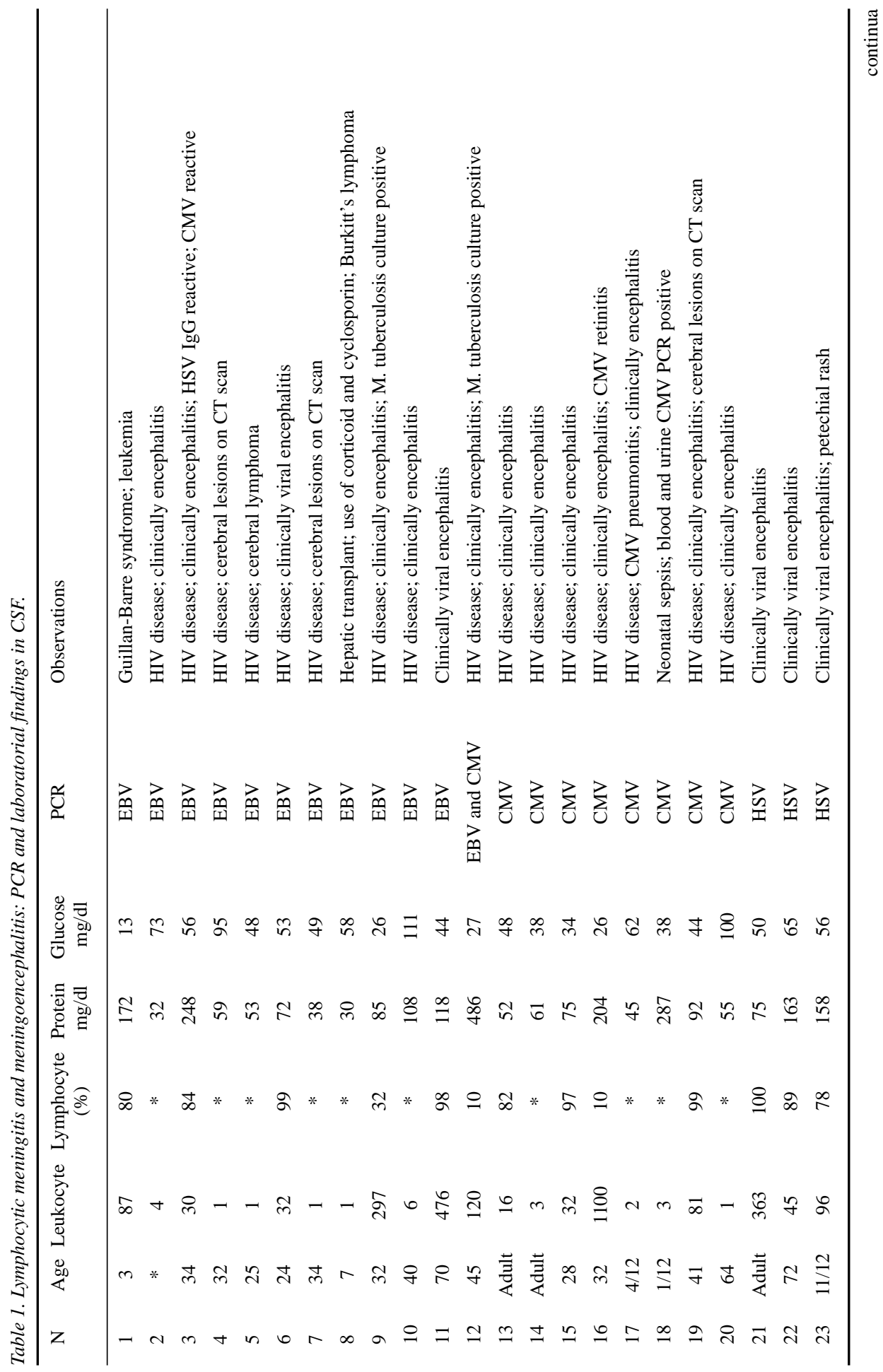



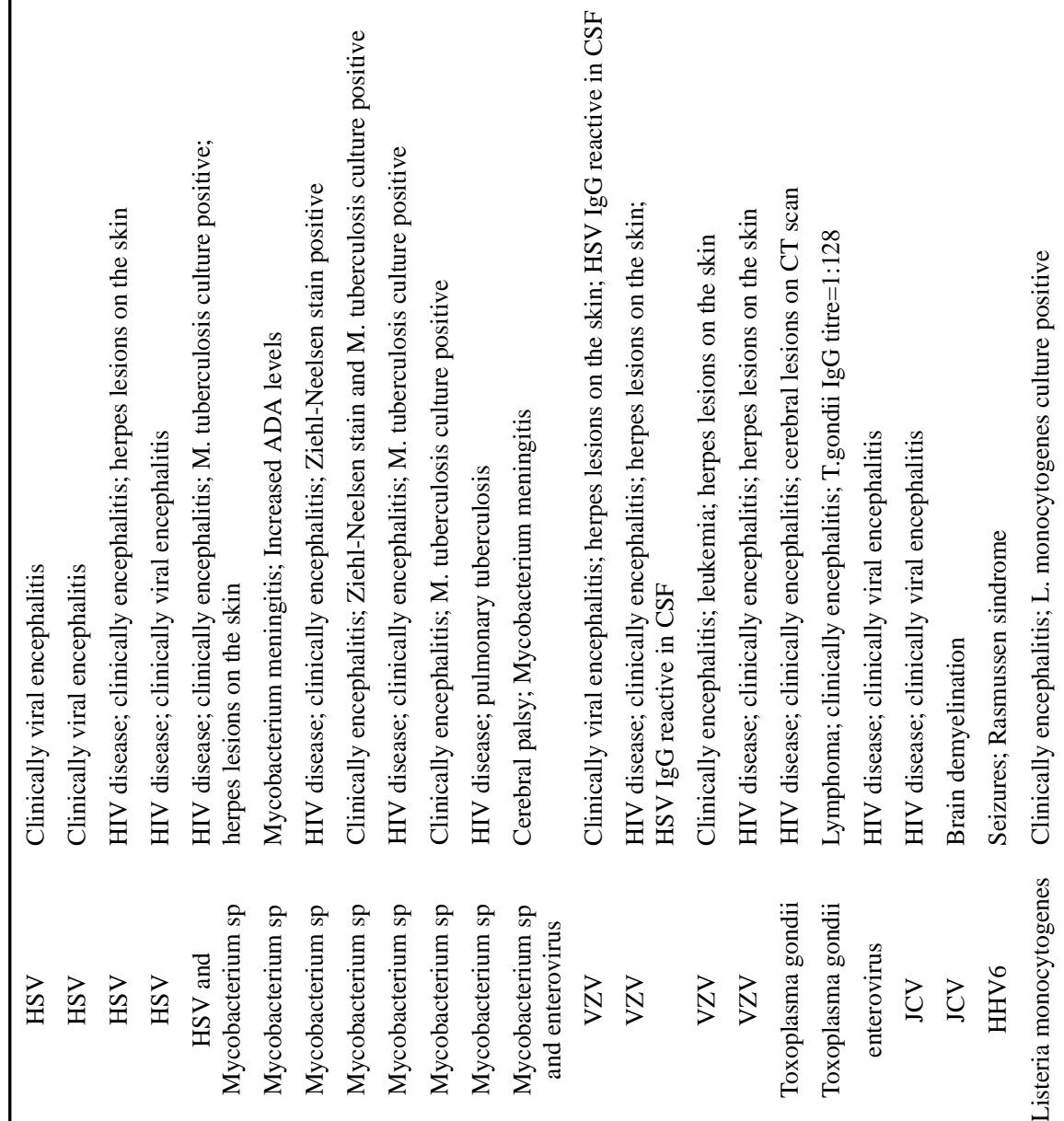

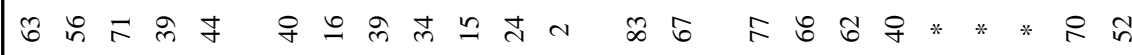

๙

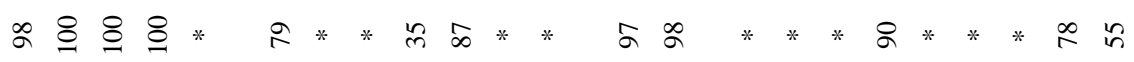

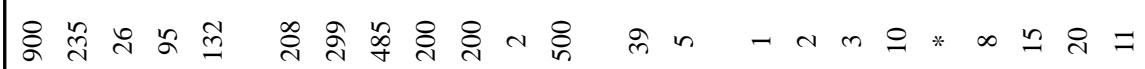

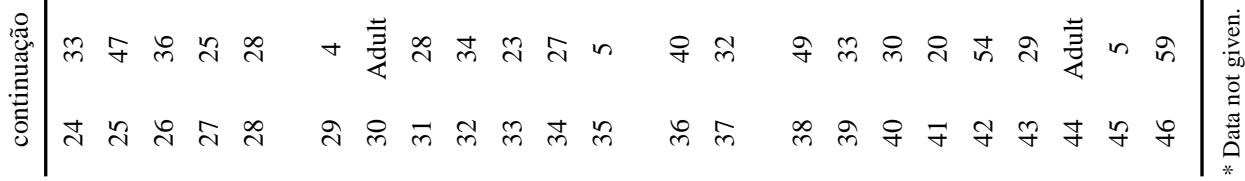


organisms were combined: enterovirus, HSV and VZV; CMV, EBV and HHV6; LCMV, measles virus and mumps virus. The other microorganisms were amplified with individual primer PCR assays.

Primary PCR amplifications were performed in a solution of total volume $50 \mu$ l containing $20 \mu \mathrm{l}$ of

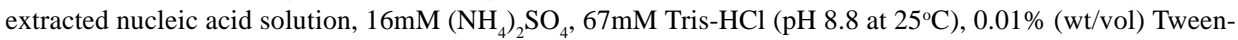
20 (PCR buffer, Advanced Biotechnologies Ltd, Epsom, UK), 1.5mM MgCl, $0.25 \mathrm{mM}$ of each deoxynucleotide triphosphate (Advanced Biotechnologies Ltd), 0.1 $\mu \mathrm{M}$ of each oligonucleotide primer (R\&D Systems Ltd, Abingdon, UK), and 0.625 unit of Taq polymerase (manufacturer's units; Advanced Biotechnologies Ltd). For the amplification of viruses with an RNA genome, 0.1 unit of Moloney murine leukaemia virus reverse transcriptase (manufacturer's units; Advanced Biotechnologies Ltd, Epsom, UK) was included for the specific antisense oligonucleotide primed reverse transcription of the genomic RNA. For the detection of DNA genomes, $10 \mu \mathrm{l}$ of the extracted nucleic acid was added to the PCR, whereas for RNA genome detection $20 \mu \mathrm{l}$ of nucleic acid was used.

Secondary amplifications with nested primers were performed on $2 \mu$ of the primary reaction solution. Identical concentrations of reagents to those in the primary PCR were used but in a total volume of $25 \mu \mathrm{l}$.

PCR thermal cycling incubations used were as follows: reverse transcription (where appropriate) and initial amplification was performed in a single reaction by incubation at $37^{\circ} \mathrm{C}$ for 15 minutes (for RNA genome detection) and $94^{\circ} \mathrm{C}$ for 40 seconds preceding 33 cycles of 20 second incubations at $94^{\circ} \mathrm{C}$, the appropriate annealing temperature and $72^{\circ} \mathrm{C}$; further amplification with nested primers was by 33 cycles of 20 second incubations at $94^{\circ} \mathrm{C}$, the appropriate annealing temperature and $72^{\circ} \mathrm{C}$. All thermal cycling was performed using PE Applied Biosystems 9600 machines. Amplification products were identified by their molecular weight following electrophoresis of $10 \mu \mathrm{l}$ of the secondary reaction mixture through an ethidium bromide-stained $2 \%$ agarose gel and UV light transillumination. The average duration of tests was 6 hours.

Carry over contamination by amplified product was avoided with strict physical separation of pre- and post- amplification processes and would have been detected using the multiple nucleic acid extraction and amplification controls incorporated into each assay batch.

External quality assessment was performed by testing a panel of 20 coded specimens (CSF, water, and diluted viral cultures) sent by the Public Health Laboratory, Oxford, UK. For some of the PCR assays an accurate measurement of the molecular sensitivity of detection was made by determining the end-point dilutions of well characterized virus preparations ${ }^{11}$ at which a positive PCR result was obtained.

\section{RESULTS}

A total of 383 CSF specimens from patients with clinical and laboratory indication of aseptic meningitis or encephalitis were tested using the PCR protocol. A positive PCR result was obtained in 46 specimens (12.0\%). The most prevalent microorganisms were EBV (11 cases); CMV (8); HSV (7); Mycobacterium genus (6); VZV (4);T. gondii (2); JC virus (2); HHV6 (1); enteroviruses (1) and L. monocytogenes (1). In three specimens, two microorganisms were detected: HSV and Mycobacterium genus, enterovirus and Mycobacterium genus, CMV and EBV. Table 1 shows the positive PCR results and their correlation with other laboratory findings.

For the first 280 specimens from which nucleic acid was either amplified without extraction (DNA genomes), or by using an in-house method (RNA genomes), $6.1 \%$ of the cases were positive by PCR. For the remaining 103 specimens from which nucleic acid was extracted using the QIAGEN QIAamp kit, the rate of positive PCR results was $28.2 \%$.

PCR sensitivity was calculated for CMV, HSV type 1 (HSV-1), measles virus, mumps virus and poliovirus type 2 (Table 2). In the external quality assessment exercise complete concordance in the results achieved was found between the two laboratories (data not shown).

\section{DISCUSSION}

The difficulty in making a laboratory diagnosis using traditional techniques in cases of aseptic meningitis and encephalitis has stimulated the development of studies using PCR assays. So far, results for a number of organisms have shown that PCR increases diagnostic sensitivity, specificity, and speed ${ }^{13-17}$. 
Table 2. Calculation of PCR sensitivity.

\begin{tabular}{lcccccc}
\hline & $\begin{array}{c}\log \\
\text { infectivity } \\
\left(\mathrm{TCID}_{50} / \mathrm{ml}\right)^{1}\end{array}$ & $\begin{array}{c}\log \\
\mathrm{nvp} / \mathrm{ml}^{2}\end{array}$ & $\begin{array}{c}\log \\
\left(\mathrm{PCRD}_{50} / \mathrm{ml}^{3}\right.\end{array}$ & $\begin{array}{c}\log \\
\text { nvp/TCID } \\
(\text { antilog })\end{array}$ & $\begin{array}{c}\log \\
{\mathrm{nvp} / \mathrm{PCRD}_{50}}_{(\text {antilog })}\end{array}$ & $\begin{array}{c}\log \\
\mathrm{TCID}_{50} / \mathrm{PCRD}_{50} \\
\left(\text { antilog }^{4}\right.\end{array}$ \\
\hline CMV & 4.5 & 8.58 & 8.0 & $4.08(12023)$ & $2.58(380)$ & $-3.5(0.0003)$ \\
HSV-1 & 6.5 & 8.2 & 9.0 & $1.7(50)$ & $2.2(158)$ & $-2.5(0.003)$ \\
measles virus & 3.3 & - & 4.0 & - & - & $-0.7(0.2)$ \\
mumps virus & 4.0 & - & 3.0 & - & - & $1(10)$ \\
poliovirus type 2 & 7.0 & 8.03 & 6.5 & $1.03(11)$ & $1.53(34)$ & $3(1000)$ \\
\hline
\end{tabular}

${ }^{1}$ Infectious dosage of tissue culture in which $50 \%$ of inoculated cells were infected.

${ }^{2}$ Number of viral particles counted by electronic microscope.

${ }^{3}$ Refers to the highest dilution detectable by PCR, adjusted for concentration/ml. For example, if in $10 \mu l$ the test is positive for up to $10^{-4}$, the suspension contains $10^{6} \mathrm{PCRD}_{50}$.

${ }^{4}$ Number of infectious units in $1 \mathrm{ml}$ specimen required to have a positive PCR.

The primary objective of developing a PCR protocol for the detection of the more common organisms that cause aseptic meningitis and encephalitis was to establish a simple and robust routine diagnostic protocol. The protocol developed has assays for 17 of the pathogens that are known to commonly cause CNS symptoms. To determine testing order in this protocol these pathogens were arranged into three groups using the criteria of frequency of occurrence, immune status of the patient, and clinical suspicion. The use of three multiplex PCR assays for the more commonly performed tests (enteroviruses, HSV, VZV; CMV, EBV, HHV6; LCMV, measles virus, mumps virus) made the protocol less time consuming and less expensive. The sensitivity of detection of the viruses by these multiplex assays was not reduced when compared to the respective PCR assay performed with individual primer sets: the end point dilutions of the control cultures positive in the assays were within $1 \log$ of each other (data not shown).

Three-hundred and eighty-three patients with suspected aseptic meningitis and encephalitis were tested using this protocol. It is interesting to compare the results of this series with those from a similar series performed in the UK and reported previously ${ }^{10}$. Overall, a PCR assay was positive in 46 cases $(12.0 \%$ ), higher than the $6.6 \%$ rate obtained in the UK. It should be noted that in that series direct detection of DNA genomes was used without nucleic acid extraction, and that when the similarly processed subset of patients from the Brazilian series is compared to the UK series a similar rate of organism detection is observed.

With the replacement of the in-house nucleic acid extraction methods by the QIAamp extraction kit in this series, the PCR positive detection rate increased from $6.1 \%$ to $28.2 \%$. This is a much greater increase than that observed when the same change in methodologies was made in the UK: there the increase was from 6.6 to $8.2 \%$. The changes in nucleic acid extraction were made when it was suspected that PCR inhibitors were present in some CSF specimens. The organisms most commonly detected were those with a DNA genome and this may explain the discrepancy in the positivity rate between the two series: in the UK series enteroviruses were the most commonly detected infection and this assay was unaffected by the inhibitory effects of CSF as an in-house RNA extraction system was used. In the two UK series that have been reported an increase was observed after the introduction of the QIAamp procedure in the detection rate of two herpes viruses but not of enteroviruses ${ }^{18}$.

Of the 46 patients with a positive PCR result, 32 were immunocompromised ( 27 had HIV infection, 4 had lymphoreticular neoplasia, and one patient was immunosuppressed following hepatic transplant). Overall in this series 125 patients (32.6\%) were known to have HIV infection, much 
higher than in the two UK series $(3.3 \%$ and $4.0 \%)$. It is interesting to note that among the immunocompromised patients, 14 had normal CSF cytology, and three had dual CNS infection. The large number of CSF samples positive for EBV DNA raises the question of whether this virus is directly involved in CNS disease pathogenesis, whether innocent virus reactivation is detected, or whether latent EBV genome was detected due to the high sensitivity of the technique ${ }^{19,20}$.

In two patients with HIV infection and a clinical diagnosis of tuberculosis meningitis (Table 1, samples 9 and 12), the PCR assay failed to detect Mycobacterium DNA but Mycobacterium tuberculosis was grown from both samples. In one of these samples, PCR for EBV DNA was positive, and in the other PCR detected both EBV and CMV DNA. These false-negative results, and the high incidence of tuberculosis infection in the population of Porto Alegre, has lead us to introduce a PCR assay using primers specific for $M$. tuberculosis ${ }^{21}$ and with apparent higher molecular sensitivity: when the culture positive specimens were tested with the new PCR assay M. tuberculosis DNA was amplified in each case.

In our laboratory, the introduction of molecular techniques and the adoption of a protocol for determining testing of CSF by PCR has greatly improved the laboratory diagnosis of aseptic meningitis and encephalitis. PCR has shown great potential for the diagnosis of CNS infection, however difficulties such as the interpretation of finding EBV and CMV in the CSF of immunocompromised patients remain.

\section{REFERENCES}

1. Lipton JD, Schafermeyer RW. Central nervous system infections: the usual and the unusual. Ped Emergencies 1995;13:417-443.

2. Anderson M. Management of cerebral infection. J Neurol Neurosurg Psychiatry 1993;56:1243-1258.

3. Mullis KB. The unusual origin of the polymerase chain reaction. Sci Am 1990; April:36-43.

4. Jeffery KMJ, Bangham CRM. Recent advances in the laboratory diagnosis of central nervous system infections. Curr Opin Infectious Diseases 1996;9:132-137.

5. Eisenstein BI. The polymerase chain reaction: a new method of using molecular genetics for medical diagnosis. N Engl J Med 1990;18:178-183.

6. Bell J. The polymerase chain reaction. Immunol Today 1989;10:351-356.

7. Guffond T, Dewilde A, Lobert P-E, Caparros-Lefebvre D, Hober D, Wattre P. Significance and clinical relevance of the detection of herpes simplex virus DNA by the polymerase chain in cerebrospinal fluid from patients with presumed encephalitis. Clin Infect Dis 1994;18:744-49.

8. Lakeman FD, Whitley RJ, and the National Institute of Allergy and Infectious Diseases Collaborative Antiviral Study Group. Diagnosis of herpes simplex encephalitis: application of polymerase chain reaction to cerebrospinal fluid from brain-biopsied patients and correlation with disease. J Infect Dis 1995;171:857-863.

9. Sawyer MH, Holland D, Aintablian N, Connor JD, Keyser EF, Waeker NJ. Diagnosis of enteroviral central nervous system infection by polymerase chain reaction during a large community outbreak. Pediatr Infect Dis J 1994;13:177-182.

10. Read S, Wareing S, Jeffery K, Bangham C. Further development of multiplex PCR assays for the laboratory diagnosis of viral meningitis and encephalitis. PHLS Microbiology Digest 1997;14:202-205.

11. Read SJ, Jeffery KJM, Bangham CRM. Aseptic meningitis and encephalitis: the role of PCR in the diagnostic laboratory. J Clin Microbiol 1997;35:691-696.

12. Boom R, Sol CJA, Salimanns MMM, Jansen CL, Wertheim-van Dillen PME, van de Noorda J. Rapid and simple method for purification of nucleic acids. J Clin Microbiol 1990;28:495-503.

13. Landgren M, Kyllerman H, Bergstrom T, Dotevall L, Ljungstrom L, Rickstein. Diagnosis of Epstein-Barr virus-induced central nervous system infections by DNA amplification from cerebrospinal fluid. Ann Neurol 1994;35:631-635.

14. Echeverria JM, Casas I, Tenorio T, de Ory F, Martinez-Martin P. Detection of varicella-zoster virus-specific DNA sequences in cerebrospinal fluid from patients with acute aseptic meningitis and no cutaneous lesions. J Med Microbiol 1994;43:331-335.

15. Gozlan J, Amrani ME, Baudrimont M et al. A prospective evaluation of clinical criteria and polymerase chain reaction assay of cerebrospinal fluid for the diagnosis of cytomegalovirus-related neurological diseases during AIDS. AIDS 1995;9:253-260.

16. Fong IW, Briton CB, Luinstra KE, Toma E, Mahony JB. Diagnostic value of detecting JC virus DNA in cerebrospinal fluid of patients with progressive multifocal leukoencephalopathy. J Clin Microbiol 1995;33:484-485.

17. Liu PYF, Shi ZY, Lau YJ, Hu BS. Rapid diagnosis of tuberculous meningitis by a simplified nested amplification protocol. Neurology 1994;44:1161-1164.

18. Read SJ, Kurtz JB. Laboratory diagnosis of common viral infections of the central nervous system by using a single multiplex PCR screening assay. J Clin Microbiol 1999;37:1352-1355.

19. Kitchin PA, Bootman JS. Quality control of the polymerase chain reaction. J Med Virol 1993;3:107-114.

20. Jeffery KJM, Read SJ, Peto TEA, Mayon-White RT, Bangham CRM. Diagnosis of viral infections of central nervous system: clinical interpretation of PCR results. Lancet 1997;349:313-7.

21. Sechi LA, Pinna MP, Sanna A et al. Detection of Mycobacterium tuberculosis by PCR analysis of urine and other clinical samples from AIDS and non-HIV-infected patients. Molecullar and Cellular Probes 1997;11:281-285. 